
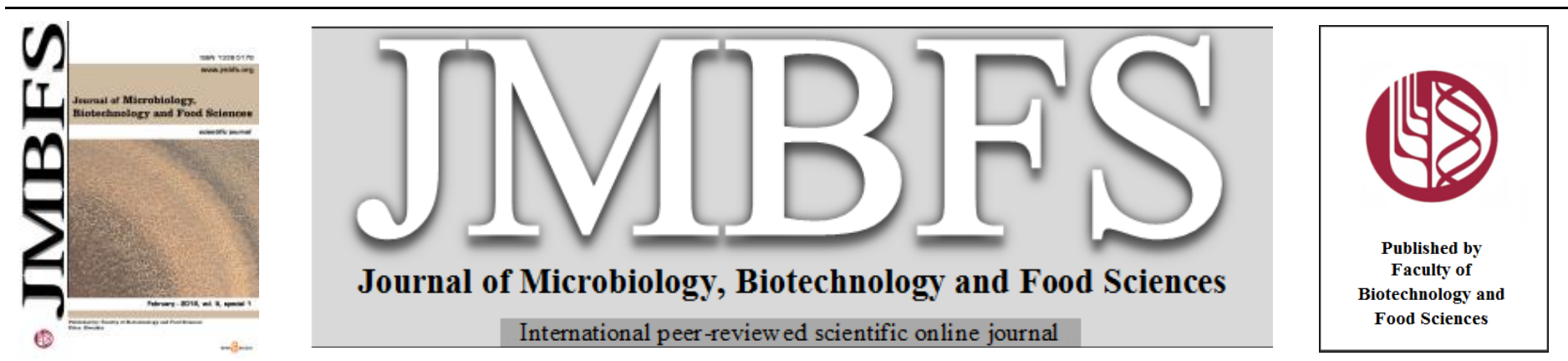

\title{
STIMULATORY EFFECT OF AMYGDALIN ON THE VIABILITY AND STEROID HORMONE SECRETION BY PORCINE OVARIAN GRANULOSA CELLS IN VITRO
}

\author{
Marek Halenár ${ }^{* 1}$, Eva Tušimovál, Anna Nynca ${ }^{2}$, Agnieszka Sadowska $^{2}$, Renata Ciereszko ${ }^{2}$, Adriana Kolesárovál
}

Address(es):

${ }^{1}$ Department of Animal Physiology, Faculty of Biotechnology and Food Sciences, Slovak University of Agriculture in Nitra, Tr. A. Hlinku 2, 94976 Nitra, Slovak Republic.

${ }^{2}$ Department of Animal Physiology, University of Warmia and Mazury, Olsztyn, Poland.

*Corresponding author: halenarmarek@gmail.com

doi: 10.15414/jmbfs.2016.5.special1.44-46

\section{ARTICLE INFO}

Received 11. 12. 2015

Revised 12. 1. 2016

Accepted 21. 1.2016

Published 8. 2. 2016

Regular article oPEN $\partial_{\text {ACCESS }}$

\begin{abstract}
Amygdalin has been one of the most popular "alternative cancer cures" in many European and South American countries. Its anticancer, anti-inflammatory activity and other medicinal benefits have been known for many years. The objective of this in vitro study was to examine the potential impact of amygdalin on the cell viability and production of steroid hormone testosterone by porcine ovarian granulosa cells. Granulosa cells were isolated from porcine ovaries and subsequently cultured without (control) or with amygdalin at various doses $(1 ; 10 ; 100 ; 1000$ and $10000 \mu \mathrm{g} / \mathrm{mL})$ for $24 \mathrm{~h}$. The cell viability was determined by alamarBlue ${ }^{\mathrm{TM}}$ reagent and release of testosterone was assayed by ELISA. Obtained results showed a significant $(\mathrm{P}<0.05)$ increase of testosterone secretion only at the highest dose of amygdalin $(10000 \mu \mathrm{g} / \mathrm{mL})$. Other experimental doses of amygdalin did not affect the testosterone production. Moreover, amygdalin treatment strongly enhanced the viability of ovarian granulosa cells. The viability was significantly $(\mathrm{P}<0.05)$ stimulated after amygdalin treatment at all used doses, except the highest concentration $(10000 \mu \mathrm{g} / \mathrm{mL})$. To conclude, application of amygdalin to culture media positively affected cell viability, but not highest dose $(10000 \mu \mathrm{g} / \mathrm{mL})$, and stimulated testosterone release by porcine ovarian cell. Present results could help to reveal the potential impact of amygdalin on cellular growth, as well as its mechanism of action in processes of ovarian steroidogenesis.
\end{abstract}

Keywords: Amygdalin, cell viability, testosterone, ovarian granulosa cells

\section{INTRODUCTION}

Natural plant origin products like amygdalin are still a major part of traditional medicine More than $50 \%$ of cancer patients in Europe use complementary/ alternative medicine (CAM) instead of, or combined with, conventional therapy (Nabavizadeh et al., 2011; Huebner et al., 2014). Amygdalin has been one of the most popular "alternative cancer cures" in many European and South American countries for long period (Chang et al., 2006; Hwang et al., 2008; Makarević et al., 2014).

This natural substance is occurring in the seeds of various plant species, belonging to the Rosaceae family, such as bitter almonds, apricots, apples and other. Its anticancer, anti-inflammatory activity and other medicinal benefits have been known for many years. This bioactive compound is composed of glucose, benzaldehyde, which induces an analgesic action, and hydrocyanic acid, which is an anti-neoplastic compound (Fukuda et al., 2003; Chang et al., 2006). $\beta$ glucosidase, one of the enzymes that catalyzes the release of cyanide from amygdalin, is present in the human small intestine and is also found in a variety of common foods (Strugala et al., 1995; Deng et al., 2002). In the late 1970s and early 1980s, amygdalin was reported to selectively kill cancer cells at the tumor site without systemic toxicity and to effectively relieve pain in cancer patients (Ellison et al., 1978). Nowadays, there are statistics described that by 1978 more than 70,000 patients with cancers in the United States have been treated with amygdalin (Moss, 2005; Makarević et al., 2014; Qian et al., 2015). However, the use of the drug was discouraged when it was demonstrated that amygdalin is metabolized in the body to release significant amount of cyanide thus leading to cyanide poisoning (Chandler et al., 1984; Bromley et al., 2005). Numerous studies have demonstrated the beneficial properties of amygdalin and its ability to effectively induce cell death (Zhou et al., 2012; Chen et al., 2013), Nevertheless, proponents consider amygdalin a natural cancer cure, whereas opponents warn that amygdalin is ineffective and even toxic (Makarević $\boldsymbol{e t}$ al., 2014).

The endocrine signaling molecules represent source of communication between several organs, as well as specific cell populations. Testosterone, one of the steroid hormones, plays a key role in ovarian cycle, folliculogenesis, cell proliferation, and also in programmed cell death (Graham et al., 1997; Sirotkin, 2014). Unfortunately, there is still no scientific evidence related to the potential effect of amygdalin on the healthy, non-pathologic cells.

This in vitro study demonstrates the potential effect of amygdalin on the cell viability and production of steroid hormone by porcine ovarian granulosa cells (GCs).

\section{MATERIAL AND METHODS}

\section{Preparation, culture and processing of granulosa cells from ovaries}

Ovaries from non-cyclic pigs were obtained from healthy Slovakian White gilts without obvious reproductive abnormalities. The ovaries were transported to the laboratory in containers at $4{ }^{\circ} \mathrm{C}$ and washed in sterile physiological solution. The follicular fluid was aspirated from 3-5 mm follicles. The granulosa cells (GCs) were isolated by centrifugation for $10 \mathrm{~min}$ at $200 \mathrm{xg}$ followed by washing in sterile DMEM/F12 1:1 medium (BioWhittaker ${ }^{\mathrm{TM}}$, Verviers, Belgium) and resuspended in the same medium supplemented with $10 \%$ fetal calf serum (BioWhittaker $^{\mathrm{TM}}$, Verviers, Belgium) and $1 \%$ antibiotic-antimycotic solution (Sigma, St. Louis, Mo, USA) at the final concentration of $10^{6}$ cells $/ \mathrm{mL}$ (as detected by a haemocytometer). Portions of the cell suspension were dispensed to 24-welled culture plates $\left(\mathrm{Nunc}^{\mathrm{TM}}\right.$, Roskilde, Denmark, 1ml/well; for Enzyme Linked Immuno Sorbent Assay, ELISA). The well plates were incubated at $37^{\circ} \mathrm{C}$ and $5 \% \mathrm{CO}_{2}$ in humidified air until a $75 \%$ confluent monolayer was formed (4-5 days), at this point, the medium was renewed and ovarian granulosa cells were incubated with the same supplements (DMEM/F12 1:1 medium, 10\% fetal calf serum, without $1 \%$ antibiotic-antimycotic solution) and without (control) or with amygdalin $(1,10,100,1000,10000 \mu \mathrm{g} / \mathrm{mL})(\geq 99 \%$ purity, from apricot kernels, Sigma-Aldrich, St. Louis, Mo, USA) for $24 \mathrm{~h}$. After $24 \mathrm{~h}$ of incubation the culture media from well plates were aspirated and kept at $-80^{\circ} \mathrm{C}$ for subsequent assay. The concentrations of steroid hormones progesterone and estradiol-17 $\beta$ were 
assayed using ELISA (Dialab, Wiener Neudorf, Austria) according to the manufacturer's instructions.

\section{Cell viability test}

The cell viability was determined after treatment of amygdalin by alamarBlue $\mathrm{T}^{\mathrm{TM}}$ reagent (BioSource International, Nivelles, Belgium) (Bannerman et al., 2001; Nynca et al., 2009). This assay is based on the ability of living and metabolically active cells to convert the oxidized indigo blue state of alamarBlue dye into the reduced pink state. Isolated granulosa cells were cultured in 96-well plates/100 $\mu \mathrm{L}$ at the concentration $0.1 \times 10^{5}$ cells per well $\left(37^{\circ} \mathrm{C}, 5 \% \mathrm{CO}_{2}\right)$. After preincubation $(48 / 72 \mathrm{~h})$, the monolayer of granulosa cells was cultured for 24 hours with or without amygdalin $(1,10,100,1000,10000 \mu \mathrm{g} / \mathrm{mL}$ ) or DMSO (as a positive control). Twenty four hours before the end of cell culture, alamarBlue ${ }^{\mathrm{TM}}$ dye was added to all wells. Thereafter, alamarBlue ${ }^{\mathrm{TM}}$ reduction was measured spectrophotometrically at 565 and $595 \mathrm{~nm}$ and expressed as a percentage according to the manufacturer calculations. All analyses were performed in quadruplicates.

\section{Statistical Analysis}

Each experimental group was represented by four culture wells of granulosa cells (each dose $=4$ replicates, biological parallels). Assessments of hormone concentrations in the incubation media were performed in duplicates. The data are presented as means of values obtained from one experiment using separate pools of ovaries from 10-12 animals. The significance of differences between the control and experimental groups was evaluated by One-Way ANOVA (Dunnett's multiple comparison test) using the statistical software GraphPad Prism 3.01 (GraphPad Software Inc., San Diego, CA, USA). The data are expressed as means \pm SEM. Differences were compared for statistical significance at the $p$ level less than $0.05(P<0.05)$.

\section{RESULTS}

\section{The effect of amygdalin on viability of porcine ovarian granulosa cells in vitro}

The viability of granulosa cells isolated from porcine ovaries was assayed after amygdalin application (Fig.1). Amygdalin aplication led to a significant $(\mathrm{P}<0.05)$ stimulation in viability of ovarian granulosa cells, compared to control cells. Viability was stimulated by the increasing doses of amygdalin $(1,10,100,1000$ $\mu \mathrm{g} / \mathrm{mL}$ ). Whereas, the highest metabolic activity was detected after exposure of amygdalin at dose $1000 \mu \mathrm{g} / \mathrm{mL}$. However, the highest dose of amygdalin (10 000 $\mu \mathrm{g} / \mathrm{mL}$ ) did not affect the viability of porcine ovarian granulosa cells, in comparison to untreated control cells.

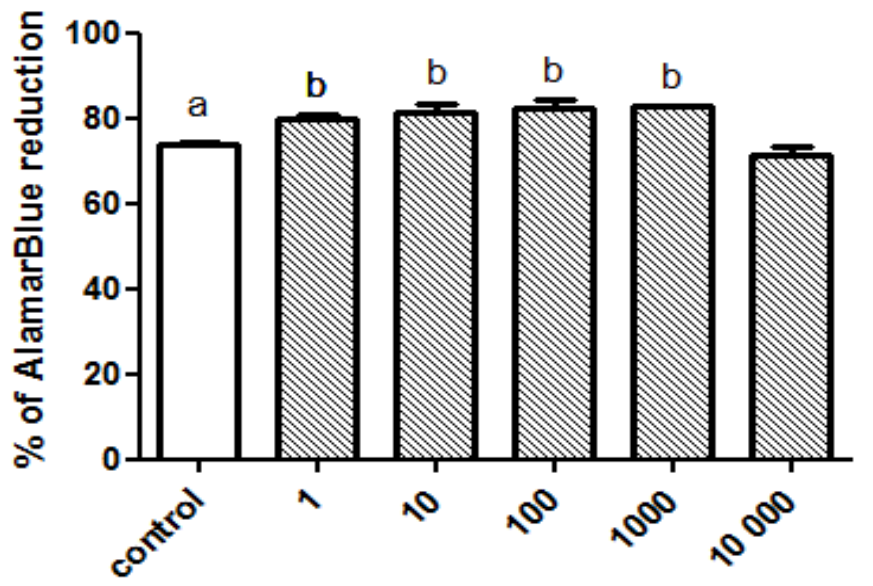

Figure 1 The viability of porcine ovarian granulosa cells incubated for $24 \mathrm{~h}$ without (control) or with amygdalin treatment $(1,10,100,1000,10000 \mu \mathrm{g} / \mathrm{mL}$ ). Signs $a, b$ denote value significantly $(P<0.05)$ different from control group. Significance of differences between the groups was evaluated by One-way ANOVA (Dunnett's multiple comparison test). The data are expressed as means \pm SEM. AlamarBlue ${ }^{\mathrm{TM}}$.

\section{The effect of amygdalin on testosterone release by porcine ovarian granulosa cells}

The release of steroid hormone testosterone by ovarian granulosa cells after amygdalin addition is shown in Figure 2. Significant $(\mathrm{P}<0.05)$ stimulation of testosterone production was observed after amygdalin treatment at highest used dose $(10000 \mu \mathrm{g} / \mathrm{mL})$, in comparison to control group without addition of the substance. However, other experimental doses of amygdalin did not affect the testosterone release by granulosa cells.

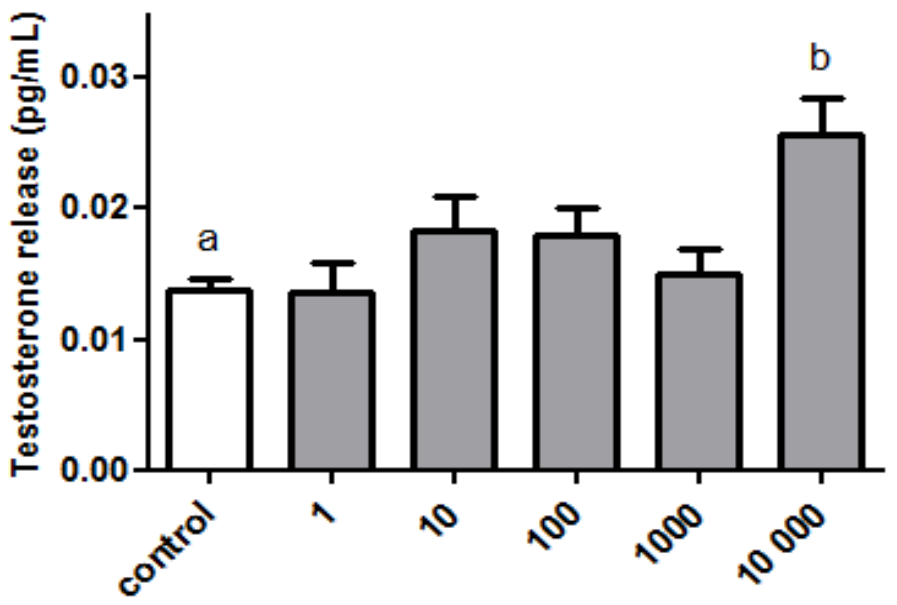

Figure 2 The effect of amygdalin on testosterone release by porcine ovarian granulosa cells. The control represents culture media without amygdalin addition; the experimental groups represent culture media supplemented with amygdalin $(1,10,100,1000,10000 \mu \mathrm{g} / \mathrm{mL})$ addition. Signs $a, b$ denote value significantly $(P<0.05)$ different from control group. Significance of differences between the groups was evaluated by One-way ANOVA (Dunnett's multiple comparison test). The data are expressed as means \pm SEM. ELISA.

\section{DISCUSSION}

The present investigation suggests stimulatory impact of amygdalin on a viability of ovarian granulosa cells, as well as the production of steroid hormone testosterone in vitro. Granulosa cells, isolated from porcine ovaries, were able to survive, grow in culture and release the steroid hormone after the experimental addition of natural compound amygdalin. Numerous studies have reported the inhibitory action of amygdalin on the proliferation and growth of different cancer cells (Syrigos et al., 1998; Chen et al., 2013; Qian et al., 2015). However, possible impact of amygdalin on the cellular growth, differentiation and death of normal, non-pathological cells remains unknown.

In our study, amygdalin strongly enhanced the viability of ovarian granulosa cells at all doses, except the highest used dose $(10000 \mu \mathrm{g} / \mathrm{mL})$. Viability of ovarian cells was stimulated by the increasing doses of amygdalin $(1,10,100,1000$ $\mu \mathrm{g} / \mathrm{mL})$. Previously, cytotoxic effect of amygdalin on human prostate cancer cells was evidenced by Chang et al. (2006). Amygdalin exhibited a dose-dependent suppression of cell viability at higher concentrations. Moreover, amygdalin is able to block the bladder cancer cell growth in vitro by diminishing of cellular regulators (Makarevic et al., 2014). Recent study carried out by Nynca $\boldsymbol{e t}$ al. 2009 demonstrated the effect of a natural phytoestrogen-daidzein on the viability of porcine ovarian granulosa cells. They found that the cell viability was not affected by daidzein application at various doses $(0.5-50 \mu \mathrm{M})$.

Previous studies described the effect of various natural substances with protective (Kolesárova et al., 2012; Halenár et al., 2013) or toxic (Ranzenigo et al., 2008; Medved'ová et al., 2011; Maruniaková et al., 2013) potential on the cellular processes in ovarian cells. In addition, the release of steroid hormone testosterone by ovarian granulosa cells after amygdalin application was observed in this examination. Increased secretion $(P<0.05)$ of testosterone by granulosa cells was detected only in experimental group with the highest dose of amygdalin (10 000 $\mu \mathrm{g} / \mathrm{mL}$ ). The present results are in accordance with our recent examination, where a stimulatory effect of amygdalin on the release of $17 \beta$-estradiol by ovarian granulosa cells was observed, too. Amygdalin treatment $(10000 \mu \mathrm{g} / \mathrm{mL})$ resulted in significant $(P<0.05)$ increase of the hormone production by porcine ovarian granulosa cells (Halenár et al., 2015). Interestingly, the presence of amygdalin at selected doses did not affect the progesterone secretion by porcine ovarian GCs.

Similarly, exposure of deoxynivalenol, resveratrol and their combination on the release of progesterone by porcine ovarian granulosa cells was studied by Kolesárová et al. (2012). Progesterone release was significantly $(P<0.05)$ stimulated by resveratrol treatment at the dose $50 \mu \mathrm{g} / \mathrm{mL}$, but not at 30 and 10 $\mu \mathrm{g} / \mathrm{mL}$. Kádasi et al. (2012) also reported a stimulatory effect of curcumin, a natural plant molecule, on the release of testosterone by porcine ovarian granulosa cells.

\section{CONCLUSION}

This study helps to reveal the potential impact of amygdalin on cellular growth, mechanism of action in processes of ovarian steroidogenesis. Application of amygdalin to culture media affected cell viability, but not the highest dose $(10000 \mu \mathrm{g} / \mathrm{mL})$, and stimulated testosterone release by porcine ovarian granulosa cells. 
Acknowledgments: This work was financially supported by the Ministry of Education, Science, Research and Sport of the Slovak Republic projects no. 1/0022/13, APVV-0304-12, and European Community under project no 26220220180: Building Research Centre „AgroBioTech".

\section{REFERENCES}

Bannerman, D.D., Tupper, J.C., Ricketts, W.A., Bennet, C.F., Winn, R.K. Harlan, J.M. (2001). A constitutive cytoprotective pathway protects endothelial cells from lipopolysaccharide-induced apoptosis. J. Biol.Chem. 276(18), 1492414932.

Bromley, J., Hughes, B.G., Leong, D.C., Buckley, N.A. (2005). Life-threatening interaction between complementary medicines: cyanide toxicity following ingestion of amygdalin and vitamin C. Ann. Pharmacother. 39(9), 1566-1569. http://dx.doi.org/10.1345/aph.1E634

Deng, Y., Guo, Z.G., Zeng, Z.L., Wang, Z. (2002). Studies on the pharmacological effects of saffron (Crocus sativus L.). Chin. J. Chin. Mater. Med. 27(8), 565-568.

Ellison, N. M., D. P. Byar., G. R. Newell. (1978). Special report on Laetrile: The NCI Laetrile Review. Results of the National Cancer Institute's retrospective Laetrile analysis. N. Engl. J. Med. 299, 549-552. http://dx.doi.org./ 10.1056/NEJM197809072991013

Fukuda, T., Ito, H., Mukainaka, T., Tokuda, H., Nishino, H., Yoshida, T. (2003). Anti-tumor promoting effect of glycosides from Prunus persica seeds. Biological and Pharmaceutical Bulletin, 26, 271-273. http://dx.doi.org/10.1248/bpb.26.271

Graham, J.D., Clarke, C.L. (1997). Physiological action of progesterone in target tissues. Endocrine Rev. 18, 502-519. http://dx.doi.org/10.1210/edrv.18.4.0308

Halenár, M., Medved’ová, M., Maruniaková, N., Kolesárová, A. (2015) Assessment of a potential preventive ability of amygdalin in mycotoxin-induced ovarian toxicity. Journal of Environmental Science and Health, part B, 50, 411 416. http://dx.doi.org./10.1080/03601234.2015.1011956

Halenár, M., Medved’ová, M., Maruniaková, N., Kolesárová, A. (2013) Amygdalin and its effect on animal cells. Journal of Microbiology, Biotechnology and Food Sciences, 2, 1414-1423. http://dx.doi.org/ 10.1111/jpn.12013

Huebner, J., Micke, O., Muecke, R., Buentzel, J., Prott, F.J., et al., (2014). User Rate of Complementary and Alternative Medicine (CAM) of Patients Visiting a Counseling Facility for CAM of a German Comprehensive Cancer Center. Anticancer Res, 34, 943-948.

Hwang, H.J., Lee, H.J., Kim, CH. J., Shim, I., Hahm, D.H. (2008). Inhibitory effect of amygdalin on lipopolyccharide-inducible TNF- $\alpha$ and IL- $1 \beta$ mRNA expression and carrageenan-induced rats arthritis. Journal of Microbiology and Biotechnology, 18(10), 1641-1647.

Chandler, R.F., Anderson, L.A., Phillipson, J.D. (1984). Laetrile in perspective. Can. Pharm. J. 117(11), 517-520.

Chang, H.K., Shin, M.S., Yang, H.Y., Lee, J.W., Kim, Y.S., Lee, M.H., Kim, J., Kim, K.H.,Kim, C.J. (2006). Amygdalin Induces Apoptosis through Regulation of Bax and Bcl-2 Expressions in Human DU145 and LNCaP Prostate Cancer Cells. Biological and Pharmaceutical Bulletin, 29(8), 1597-1602. http://dx.doi.org/10.1248/bpb.29.1597

Chen, Y., Ma, J., Wang, F., Hu, J., Cui, A., Wei, C., Yang, Q., Li, F. (2013) Amygdalin induced apoptosis in human cervical cancer cell line HeLa cells Immunopharmacology and Immunotoxicology, 35, 43-51. http://dx.doi.org/ 10.3109/08923973.2012.738688

Kádasi, A., Sirotkin, A.V., Maruniaková, N., Kolesárová, A., Bulla, J., Grossmann, R. (2012). The effect of curcumin on secretory activity, proliferation and apoptosis of the porcine ovarian granulosa cells. Journal of Microbiology, Biotechnology and Food Sciences, 2, 349-357.

Kolesárová, A., Capcarová, M., Maruniaková, N., Lukáč, N., Ciereszko, R.E., Sirotkin, A.V. (2012). Resveratrol inhibits reproductive toxicity induced by deoxynivalenol. Journal of Environmental Science and Health, Part A, 47, 13291334. http://dx.doi.org/10.1080/10934529.2012.672144

Makarević, J., Rutz, J., Juengel, E., Kaulfuss, S., Reiter, M., Tsaur, I., Bartsch, G., Haferkamp, A., Blaheta, R.A. (2014). Amygdalin blocks bladder cancer cell growth in vitro by diminishing cyklin A and cdk2. PLoS ONE, 9(8), 1-9. http://dx.doi.org/10.1371/journal.pone.0105590

Maruniaková, N., Kolesárová, A., Kádasi, A., Medved’ová, M., Halenár, M. Sirotkin, A.V., Grossmann, R., Bulla, J. (2013). Release of progesterone and testosterone by ovarian granulosa cells after addition of T-2 toxin and its combination with growth factor IGF-I. Journal of Microbiology, Biotechnology and Food Sciences, 2, 1864-1874.

Medved'ová, M., Kolesárová, A., Capcarová, M., Labuda, R., Sirotkin, A.V., Kováčik, J., Bulla, J. (2011). The effect of deoxynivalenol on the secretory activity, proliferation and apoptosis of porcine ovarian granulosa cells in vitro. Journal of Environmental Science and Health Part B, 46(3), 213-219. http://dx.doi.org/ 10.1080/03601234.2011.540205

Moss, R.W. (2005). Patient perspectives: Tijuana cancer clinics in the postNAFTA era. Integrative Cancer Therapies, 4, 65-86. http://dx.doi.org/10.1177/1534735404273918
Nabavizadeh, F., Alizadeh, A.M., Sadroleslami, Z., Adeli, S. (2011). Gastroprotective effects of amygdalin on experimental gastric ulcer: Role of NO and TNF- $\alpha$. Journal of Medical Plants Research, 5(14), 3122-3127.

Nynca, A., Jablonska, O., Slomczynska, M., Petroff, B.K., Ciereszko, R. (2009). Effect of phytoestrogen deidzein and estradiol on steroidogenesis and expression of estrogen receptors in porcine luteinized granulosa cells from large follicles. Journal of physiology and pharmacology, 60, 95-105.

Ranzenigo, G., Caloni, F., Cremonesi, F., Aad, P.Y., Spicer, L.J. (2008). Effects of Fusarium mycotoxins on steroid production by porcine granulosa cells. Animal Reproduction $\quad$ Science, $\quad 107, \quad 115-130$. http://dx.doi.org/10.1016/j.anireprosci.2007.06.023

Sirotkin, A.V. (2014). Regulators of Ovarian Functions. New York: Nova Publishers , 194

Strugala, G.J., Stahl, R., Elsenhans, B., Rauws, A.G., Forth, W. (1995). Smallintestinal transfer mechanism of prunasin, the primary metabolite of the cyanogenic glycoside amygdalin. Human Experimental Toxicology, 14(11), 895901. http://dx.doi.org/10.1177/096032719501401107

Syrigos, K.N., Rowlinson-Busza, G., Epenetos, A.A. (1998). In vitro cytotoxicity following specific activation of amygdalin by beta-glucosidase conjugated to a bladder cancer-associated monoclonal antibody. International Journal of Cancer 78(6), 712-719. http://dx.doi.org/10.1002/(SICI)10970215(19981209)78:6<712::AID-IJC8>3.0.CO;2-D

Qian, L., Xie, B., Wang, Y., Qian, J. (2015). Amygdalin-mediated inhibition of non-small cell lung cancer cell invasion in vitro. Int. J. Clin. Exp. Pathol. 8(5) 5363-5370.

Zhou, C., Qian, L., Ma, H., Yu, X., Zhang, Y., Qu, W., Zhang, X., Xia, W. (2012). Enhancement of amygdalin activated with $\beta$-D glucosidase on HepG2 cells proliferation and apoptosis. Carbohydrate Polymers, 90, 516-523. http://dx.doi.org/10.1016/j.carbpol.2012.05.073 